[Dale, R., \& Jesson, J. (1993). Mainstreaming Education: The Role of the State Services Commission. New Zealand Annual Review of Education, 2, 7-34]

\section{Mainstreaming Education: The Role of the State Services Commission ${ }^{1}$}

\section{ROGER DALE AND JOCE JESSON}

$\mathrm{T}$

he education reforms that began in New Zealand in 1987 have generated a huge literature (Middleton et al. (1990), Codd et al. (1990), Lauder and Wylie (1990) and Manson (1992) contain a representative selection of articles and references to other literature). One of the features of that literature has been the attempt to relate the education reforms to the large collection of economic and political reforms set in place by the fourth Labour Government after its election in 1984. The first, and most radical, phase of these reforms occurred during the 1984-87 Parliament. They centred on a programme of widespread economic deregulation and the curtailment and/or commercialization of state activities. They were informed and driven by a neo-liberal economic theory, known locally as "Rogernomics" after its chief begetter, the Minister of Finance in the 1984-87 Labour Government, Roger Douglas (see Holland and Boston, 1991). In this phase there were no radical changes to the education systems.

With the return of the Labour government in 1987 the reform impetus was extended to education. There were two strands to this impetus. One was the explicit application to education of the Rogernomics neo-liberal approach, this is set out in the second volume of the Treasury's brief to the incoming government (NZTreasury, 1987). The other was the setting up of the Picot task force on the administration of education whose report Administering for Excellence was published in April 1988. These two strands were distinct from each other. The Treasury brief distinguished between education as a public good and as a commodity (see Grace, 1989). The Picot Task force's terms of reference were confined to the administration of education. Where the strands come together was in the presence of a Treasury representative on the Picot task force, whose activities on the task force
8 Roger Dale and Joce Jesson

were revealed by another of its members, Peter Ramsay, to have amounted to putting pressure on the Picot members to follow "the Treasury line". ${ }^{2}$

These two interventions in education gave rise to what has been perhaps the most influential interpretation of the New Zealand education reforms, that they were led by a new right, neo-liberal ideology, that in essence they represented the extension of Rogernomics to education. This interpretation sees the education reforms as aimed at eventually privatizing education in line with the privatization of other areas of government activity. It points to the continuing interest of the Treasury in education, which it sees as being fuelled and supported by the Business Round table (BRT) and in particular, informed by the report the BRT commissioned from the neo-liberal writer on education, Stuart Sexton, (1990).

In our view this interpretation does not permit the fullest understanding of the process and impact of the New Zealand education reforms. It rests on assumptions of the clarity, coherence and feasibility of the Treasury's education programme and of its ability and willingness to put to into practice in the teeth of very widespread and virulent criticism it has received. This is not to say that the Treasury has had no influence on the education system, that it will not continue to do so or that its influence might not increase to a point where its neo-liberal programme for education will be implemented. It is to say that assuming both that these things have happened or will happen, interpreting the reforms as if they were driven largely if not exclusively by a neo-liberal ideology, and consequently failing to consider other possible interpretations, tends to produce interpretations that are less than adequate. These arguments do not examine the mechanisms of provision, funding and control of education and so leave the discussions at the ideological level.

The central point we wish to make is that the other central agency that reviews and to a degree co-ordinates the work of all government departments, the State Services Commission (SSC) has to date been a far more powerful and direct influence on the education reforms, and that that influence has been somewhat neglected in the shadow of the neoliberal argument. The length of the shadow cast by the neo-liberal argument is clear from the references in the literature to Peter Ramsay's revelation of Treasury influences in Picot. Only a minority of these references point out that in that quotation Ramsay referred to pressure 
from the SSC (who were also represented on Picot) as well as from Treasury. Further, we might doubt the extent of Treasury influence over Picot if we consider carefully the Taskforce's terms of reference and its conclusions. These do not bear the clear stamp of neo-liberal ideology. In fact, as its secretary informs us, the Picot task force explicitly considered, and rejected, the introduction of education vouchers, the key means of operationalizing the neo-liberal education programme (Gianotti, 1990). Nor do we find any suggestion in Picot, or in the Tomorrow's Schools legislation that was based on it that the state should cease to be the provider of education. Indeed, it is clear from Wilson's (1990) account of the making of the Picot report that while the SSC and Treasury interests and positions were not identical, it was the SSC that largely wrote the terms of reference for the Picot Taskforce and that much of the Picot report drew very directly on the papers and reports prepared earlier by the SSC (Wilson, 1990, Ch. 5). Wilson quotes Marijke Robinson the SSC representative on the Task force as saying: "the SSC talks about the machinery of Government while the Treasury talks about the resources" (Wilson, 1990, p. 131).

This view is supported by MacPherson (1989) who worked with the SSC during the deliberations of the Taskforce. He sees the influence of the central agencies on the Taskforce as an attempt to inhibit provider capture, which for him meant curtailing the influence of a "portfolio culture" that had begun to flout the norms of the wider political culture MacPherson (1993, p. 229) Associated with this, although the SSC should only have had a "downstream" interest in the Picot exercise, the terms of reference had already signalled the Government's concerns and intentions. The SSC therefore moved quickly on the assumption that structures in education and the practices of educational administrators were to be radically reformed (MacPherson, 1989, p. 111). MacPherson suggests some reasons why the SSC views on administration reform were influential. One is:

that they cohered with assumptions held by those in Cabinet. So called "Machinery of Government" exercises had already converted a series of Government departments and agencies into semiautonomous agencies called State Owned Enterprises ... while noone in Lange's Cabinet wanted to privatize a social service, it was generally accepted that some radical administrative surgery was long overdue in education to raise the responsiveness and legitimacy of the system (MacPherson, 1993, p. 237)
A second reason was that

alternatives to MOG perspectives were not well marketed ... By about February 1988, Picot's team were asking questions that were articulating the devolutionary administrative policy ... They were consulting in a context where MOG based metaphors, slogans and press releases were informing public policy discourse (ibid, 1990).

One useful way of comparing the positions on education held by the Treasury and the SSC is to examine the emphases contained in their respective briefings on education to the incoming government in 1990 . These briefings indicate the difference in the scope and role of the two organisations. The Treasury's concerns are considerably broader than theSSC's. The Treasury's briefing contains comments on the proper role of education, on equity issues, on the relationship between education and the government's wider concerns. The SSC's concerns are much narrower and concentrate on the machinery of the government of education. These differences in scope do not, however, account for the differences in policy emphasis in the two documents.

The most important axis of difference concerns government's role in the provision of education. The SSC's first question about the machinery of government is, "is this activity something Government should be involved in?" The answer in the briefing appears to be "yes, and at the present level of involvement". For instance, while there is a clear rejection of the appropriateness of government involvement in school transport there is no hint that government involvement in the provision of education should be even reduced. On the contrary, as we will elaborate below, the briefing pays considerable attention to how the government - and especially the SSC - can make the government role in education more effective. At the centre of the SSC briefing is the need for greater accountability and efficiency in the State education service. The key targets for improvement in the Treasury briefing, by contrast are responsiveness, choice and competition. These indicate the major thrust of the Treasury briefing - that the education service can best be improved by introducing more choice and competition. As the Treasury sees:

securing more responsive schools ... is likely to require both less centralised control of school management and a much closer link 
between parents' decisions about the placement and the funding available to each school. A process where the parents could choose freely and where state funding moved automatically with the child would put greater pressure on schools to perform (Treasury, 1990, p. 135)

Crucially, while both agencies aim to improve services at the same time as cutting costs, there is considerable variation in their strategies for bringing this about. For the SSC these dual aims are to be pursued through the greater efficiency provided by the educational reforms and the "productivity gains" and "enhanced educational outcomes" that follow from these. Its concern is to ensure the fullest possible implementation of what it perceives as the original intent of the reforms of the education sector, centering on the government strengthening its coordinating and policy development role, and improving mechanisms to bring about greater accountability of individual schools.

This is clearly not regarded as an adequate response by the Treasury. As the introduction to the education section of their briefing states:

while further reforms should help ensure better performance from money spent, significant further improvements will be difficult under the present structure of protected public sector provision. A better balance between public and private responsibility and the right form and mix of regulation, funding and provision ... would assist both fiscal and educational objectives (ibid, p. 129)

Or as it is put a little differently further on in their discussion:

Easing the conflict between fiscal and educational objectives will require better results from money already invested in education. This will necessitate a reconsideration of the role of government in the regulation, funding and provision of education services and suggests a bigger role for parents, students and competitive private providers (ibid, p. 139)

The important point for our present purposes is the lack of overlap between the two briefings. The SSC makes no reference to choice and competition or restructuring of the system, beyond that required to implement fully what it perceived to be the original intentions of the reforms. This target appears to hold even when those perceptions did not service the process of legislation and implementation. This is evident, for instance, in the re-litigation of the reforms carried through the Lough Report (see below). Treasury, on the other hand, scarcely mentions accountability or management, but seeks to fulfill the programme implied in its 1987 briefing papers, Government Management, by continuing to press for the extension of the "logic" of the market to the education sector by embedding choice and competition within it. At the core of the SSC's agenda are managerial accountability and organisational efficiency: at the core of Treasury's agenda is the creation of conditions where choice and competition can flourish. We might say that one is driven by the model of the efficient firm, the other by the logic of the market system. Our examination below will suggest that thus far, the SSC's agenda appears to have had a greater influence on the shape and processes of the education system.

This conclusion is based on the lack of impact of Treasury policies as well as the relative effectiveness of the SSC's operations in the education sector. There are a number of conditions that would have to be in place for the Treasury agenda to be implemented. One of course is that alternatives exist, or can be put in place, to current provision. This is particularly difficult where most schools in the country do not have "real competition" and the dispersal of population makes it difficult to create competition for pupils between schools many of which are regarded (by Treasury and the SSC) as already too small. A second absent condition is that there could be considerable costs in setting up the competitive system - assisting private providers, for instance - and the fiscal pressures on the government clearly preclude such expenditure in the short term. The third absence is a workable or feasible model that allows schools to be simultaneously "responsive" to pupils, parents local communities and national educational priorities. It is clear that there is likely to be conflict as well as consensus between all of these groups. This is recognised by Sexton, who rejects any idea of a centrally prescribed national curriculum as being an interference with the market: this view Treasury might find difficult to square with its preference for economically relevant priorities to be set for education, and its desire to see equity goals more adequately addressed.

In the remainder of this paper we will seek to give substance to our argument about the importance of the SSC on the form and direction of the education system. In brief, the argument is that through the intervention of the SSC in both their framing and implementation the 
education reforms have not had an educational agenda but have been part of the overall process of reforming public administration. The purpose of the reforms is to "mainstream" the education system, to remove from it any special treatment that may be argued for on the basis of special needs. We will also argue that the combination of the forms taken by the education reforms, the state sector reforms, and the industrial relations reforms has created a situation where the SSC has come to have at least as great an influence on the operation of the education system as the Ministry of Education. We shall argue finally that though this influence is not centrally or explicitly informed by educational needs, nevertheless it has educational consequences.

\section{SSC: Background}

We shall try to demonstrate these points by first setting out the background to and the principles of the theory behind the SSC's position on the machinery of government and how they were put into effect. We shall then look at three particularly important examples of this approach at work in the education sector: the Lough Report of 1990, the SSC's role in wage bargaining and the 1992 Education Amendment Bill (No. 5).

We have argued that the SSC's concentration on altering the machinery of government enabled it to seize that initiative in forming the fundamental features of the education reforms. Though we have emphasised the concentration on accountability and efficiency these terms are not self-explanatory and it is important to indicate their origins and how they are being used in this context. The most useful approach may be to start with what these principles have been invoked to counter. Without doubt the SSC's bete noir is "provider capture". We have already mentioned MacPherson's definition (based on his experience in the SSC) of producer capture: the promotion of portfolio capture at the expense of mainstream government culture. There are regular references to excessive provider involvement (at school level, and at the national level through the work of the teacher unions) at the expense of the consumers of education. The extent of this capture is registered in the briefing to the incoming government in 1990. It is worth quoting Para. 34 of that paper to give the flavour of the SSC's position towards education professionals.
34. The State Services Commission queries the efficiencies and objectivity of the predominant mode of policy development used by the Ministry.

Because of the extent of professional/union capture that exists in the education sector, we doubt that the Minister can expect to receive advice that is objective and balanced. We also have concerns about the extent to which teacher unions are heavily involved in the central policy development process. As well as having regular contact with trustees at the local level, the teacher unions have had weekly consultations with the Minister. This is a situation not evident in other portfolio areas. (SSC, 1990, p. 8)

The SSC's highest profile role concerns the appointment of chief executive officers of government ministries. More important for our purposes is that it provides advice on a range of topics including machinery of government, performance management in the State sector, EEO and good employer provisions and it also carries out performance reviews of Chief Executives and departments (SSC, 1991, p. 134)

The basis of that work is the State Sector Act of 1988 which applied to education from October 1, 1989, when the Tomorrow's Schools legislation came into effect. In the 1984-87 Labour Government, "it fell to the SSC to put "practical flesh" on the "theoretical bones" of the proposals for state sector restructuring contained in the Treasury briefing papers" (Henderson, 1990, p. 343). This meant, in essence, creating State Owned Enterprises which would transform government trading departments into "successful business enterprises". With the SOE legislation completed in early 1987, "the attention of the government and the SSC turned to the non-trading departments of the state, the "core" public service" (ibid, p. 346). The mechanism for doing this was the State Sector Act. At its centre was the replacement of the Westminster model of public administration, based on clear political neutrality, a unified career civil service with security of tenure and promotion by merit. In its place, all government departments were to be headed by CEOs who were to be engaged on 5 year contracts and to take full responsibility for appointments to and the performance, of their department. Beyond this was a set of requirements for the operation of especially the industrial relations components of government departments to be monitored by the SSC. CEOs were 
required to act as good employers and to set in place EEO programmes. There was to be much greater flexibility in setting pay and conditions: "'Departmentalism' - in employment practices, personnel management and pay fixing - has been reasserted over the emphasis on a career service contained in earlier legislation" (ibid, p. 349), - with "enterprise bargaining" as the norm throughout the state sector. With this Act the SSC took over the role of negotiating pay and conditions of employment in the education service.

The relationship of the Act to the education reforms and its importance for them, are made clear by Wilson. As he puts it:

The proposals for change detail the implications for pay fixing and industrial relations the new philosophy requires. These were not taken up explicitly in Picot in detail, rather the principles to apply in the proposed reformed structures were established. The Board of Trustees was to be made accountable via the Charter, originally a contractual document but later changed to an unenforceable agreement (Codd and Gordon, 1990), the Principal became the Chief executive of the school and was made accountable via a personal contract. As with the senior executive service in the public service, principals' salaries were to be determined as the result of a performance appraisal .... As MacPherson (1989) observed, the State Services Commission might have been expected to have an interest in the downstream effects of public sector reforms; (op. cit., p. 113-4)

The effect of this provision, then, was both to make the SSC the "collective employer" in the devolved education system, and through its incorporation into the education reform procedures to create structures that facilitate the implementation of the SSC's preferred machinery and its conceptions of accountability and efficiency.

The SSC's basic assumptions in restructuring the public sector were that changes in the machinery of government could contribute to improvements in the efficiency and effectiveness of Government funded activities and services and increase accountability to funders as well as recipients/consumers. The Government would fund but not necessarily provide the service and there should be regular monitoring of the continuing need for Government intervention. Policy advice and service delivery should be contestable and managers should be allowed to manage. Any restructuring should bear in mind the principles of biculturalism and the need to improve the ability to participate in society of the disadvantaged. As well as increasing accountability, efficiency, responsiveness, etc., the restructuring should aim to enhance community participation in decision making and consumer choice.

As Whitcombe points out "A basic assumption of the State Sector Act is that the models, conditions and behaviour of the private sector can be transported directly to the public sector" (1990, p. 53) The models on which the restructuring has been based were developed and tested in the private sector. Much the most important of them is agency theory. "An agency relationship exists when a person (principal) uses the services of another (agent) to perform an agreed upon task in exchange for a reward. This undertaking can be formalized by a contract" (ibid, p. 17); a full account of the role of agency theory in the restructuring of the public sector can be found in Whitcombe (op. cit., Chapter 3) and in Boston (1991). The perceived shortcomings that the reforms were to overcome are discussed in Dale (1992).

In the State Sector Act the Minister is assumed to be the principal and the CEO the agent. This is intended not only to improve public sector efficiency but to give the government greater control, as Whitcombe points out (op. cit., p. 53). In discussing what she sees as a key paper in the application of agency theory to public administration in New Zealand, written by two members of Treasury (Scott and Gorringe, 1988), Whitcombe suggests that one key way in which the private sector model has influenced the role of control agencies ${ }^{4}$ is in their "being assigned as surrogates to fulfill the functions of a (company) board" (ibid, pp. 51-52) However, as she goes on: "If the private sector model is to be used, the role of Cabinet would equate with that of a management board. The imposition of the intervention of additional control agencies in the monitoring process seems odd. It must therefore be assumed that a pure private sector model is inadequate to accommodate the type of monitoring that the authors have in mind" (ibid, p. 52).

This also rather suggests that the central agency authors of the State Sector Act may have had some reservations about the willingness and ability of politicians to play the part assigned them in the restructuring. They have sought to set in place obstacles to any possible "backsliding" by the politicians. This view is reinforced by the concluding sentences of the foreword to the Review of the State Sector Reforms (SSC, 1991) which states "It is entirely appropriate that the public should demand high standards from its public service. These will not be achieved, 
however, in an optimal or sustained way if the response of the public's elected representatives is to intercede arbitrarily in the process rather than take steps to ensure the health of the system as a whole" (SSC, 1991, p. 3). The Review also points to difficulties in defining the relationship between central agencies, other departments and Minister. As the Review points out, the central agencies:

play a very large part in the central management of policy, purchase and ownership risks. This gives them a considerable power of position in their own right. Departments and some Ministers consider the overall impact on departments of central agencies policy advice and monitoring and review functions to be excessive .... We found a high level of disagreement between departments and central agencies on issues such as management of the Budget process and specification of outputs. Each side tended to be cynical about the motives of the other and to attribute criticism to ignorance or self interest (ibid, pp. 70-71).

What we have argued so far is that the SSC's agenda is the extension of its machinery of government reforms to the education sector, to make it more accountable and efficient, to resist "provider capture" and to remove any lingering claims education may have to special treatment. In discussing what was meant by accountability and efficiency, however, we have noted an extension of the monitoring role to one that may at times amount to control, based in mistrust of politicians and Ministers and their ability to resist "portfolio culture". This may be expected to be especially strong in education given both its traditional institutional embeddedness and the strength, coherence and pervasiveness of its professional culture.

We move now to look briefly at three important examples of SSC involvement in the education sector.

\section{The Lough Report}

Today's Schools: a Review of the Education Reform Implementation Process, otherwise known as the Lough Report after the chairman of the review team, was published in April 1990, six months after the Education Act of October 1989 brought in the reforms based on Tomorrow's Schools. Its terms of reference were to "carry out a wide range review of the processes and outcomes of this reform of education administration to date and to recommend any necessary improvements in the process or the structures." Six months hardly seems to be sufficient time for the reforms to be institutionalised to a stage that would permit the kind of evaluation called for in the terms of reference, especially since many details of the reforms were not completed by 1st October, 1989. For instance, many school charters were not signed, there were numerous disputes about funding levels and there was considerable ignorance about how the system was to work following the galvanic changes it had undergone, such as the removal of all tiers of administration between schools and Central Ministry. Indeed the Lough Report itself might better be seen as the kind of re-litigation that it was set up to respond to than as a review of the outcomes of an implementation process that was far from complete. Wilson (1990) provides evidence to support this argument. He refers to letters sent to the Government by the Treasury and the SSC in September, 1989, i.e., before the new Education Act came into effect, to suggest the holding of a six month review of the reform implementation process. The letters were motivated by concerns that:

some essential elements of reform in Tomorrow's Schools had not survived the (implementation) working parties ... [and] amongst other things, that Education sector interest groups and former employees of the Department of Education had "claimed back" aspects of the reform policy so that the model required for the operation of the new system could not operate. This was especially illustrated, they believed, by the case of the delay and possible permanent deferral of the direct funding to schools of teacher salaries. (ibid, p. 35)

Wilson points out that direct funding was supported by Treasury because it was an essential condition of the commodification of education and by the SSC because its managerial culture required the total accountability of the principal (Chief Executive) and that accountability required the principal to have to deploy "inputs" to achieve specified "outputs" (ibid, p. 37) Further support for the relitigation argument comes in Gordon's argument that:

Lough goes significantly further than Picot or Tomorrow's Schools in envisaging that the devolution of the salary component will also involve a large amount of personnel work by Boards of Trustees. The report, for example, notes that "discretion to transfer funds between 
personnel and operating budgets" and "the introduction of pay flexibility" are necessary changes to existing practices in order to further devolve personnel matters to schools. The Lough Report appears to foreshadow a more flexible industrial relations system such as that since introduced as the Employment Contracts Act 1991.

(Gordon, 1992, p. 42)

The Lough committee was made up of a representative from each of Treasury and SSC, the CEO of the Ministry of Education and a businessman in addition to its chairman, a former Treasury secretary. Its recommendations about schools were directed towards refining the structures of education administration and improving principals' and Boards of Trustees' ability to work within them. The Education Review Office was to be reduced by half and those remaining were to develop "a clear review methodology that concentrates on outputs and outcomes, which is consistent with the new administrative functions in schools proposed by this report, and which is communicated to schools" (Lough, 1990, p. 8) These recommendations were also highly significant since they attacked the possibility that the ERO could become a repository of professional rather than managerial accountability. By halving the number of staff and narrowing and tightening the reviews they were to carry out ensured that the features the central agencies saw it important to prioritize were adequately addressed. The Lough Report then "produced a number of recommendations that had the objectives of implementing the reform programme in full and consolidating the policies that had been implemented" (SSC, 1990, p. 3).

That is, the Lough Report had the intention and effect not only of bringing back the concerns of Treasury and especially the SSC to the centre of the education reforms, but also of (re-)embedding them more deeply in the new structures so bringing an end to the "backsliding" that had occurred during an implementation process influenced by the portfolio culture and professional providers. The Report demonstrates a considerable extension of the monitoring and even the machinery of government roles of the SSC towards the control and direction of the education system.

\section{Wage Bargaining}

The second example we wish to mention is the SSC's role in wage bargaining in the education sector. The State Sector Act 1988 made the SSC the "employer party", in industrial relations in the education sector. The Review of the Role of the SSC in Wage Bargaining in the Education Sector, was one of the 17 reviews of the education sector called for in the December 1990 budget and carried out by officials of the Ministry of Education, the Treasury, and the SSC. Teacher unions and School Trustees were explicitly excluded. In this particular review the Terms of Reference included the role of the SSC with respect to teachers' conditions as well as their salaries. The Review stated that:

"the employer party" role in bargaining collective agreements is supplemented by the requirement for Commission concurrence in all individual agreements in the compulsory sector (Ministry of Education, 1991a, para. 7).

The Review focuses on who should take the employer party role in the teacher wage bargaining process. It considers four candidates, the SSC, the Ministry of Education, the School Trustees' Association (STA), and individual employing boards, and discusses their claims against three criteria: the information, the incentives and the expertise to secure the best contract in the interest of fiscal accountability to the taxpayers and in the interests of the effectiveness of the institutions towards their clients, the learners and their communities (ibid, para. 11). The Review concludes and recommends that the SSC should continue in the employer party role. However the argument it provides in support of this conclusion seems rather flimsy, if its own criteria and "the interests of institutional effectiveness" are to be taken as seriously as "the interests of fiscal accountability." It acknowledges, for instance, both that

the Ministry has advantages over the Commission in two aspects it must live with the fiscal and other consequences of negotiation outcomes and so faces greater incentives to achieve efficient settlements; it has a better appreciation of possible linkages between industrial issues and other policy initiatives at national and school levels (para. 19) 
and,

in terms of detailed knowledge of the school sector [the SSC] could

lack the depth of knowledge available to the unions" (para. 14)

and that (in respect of incentives)

the principal concern is (that) the fiscal effects of the settlements fall not on the Commission but on the Ministry as manager of Vote:

Education at national and local levels (para. 16).

The reason for recommending the Commission in spite of its clear shortcomings in meeting the Review's own criteria appears to be that another, and dominant, criterion is implicitly introduced - that of "trustworthiness". This becomes apparent in the rejection of the claims of the STA and individual employing boards. While it acknowledges that the STA as a representative of the employing boards, must be involved in negotiations and "could obtain the information based on expertise to bargain on even terms with the teachers and other unions" (para. 22) the Review states that:

a difficulty would arise if STA became too closely involved with the teachers lobbies to have an effective negotiation, notwithstanding it represents all boards (para. 23).

Similarly individual boards might tend to go for short term solutions. And while they should, after bulk funding, take more responsibility for wage bargaining,

there are still roles for the Government because Boards would have increased responsibilities.... but also increased flexibility and could make trade-offs between salary costs and class sizes. They could then deflect local concern at their management into political pressure on the Government to increase inputs (para. 27).

But that this is hardly a reason to exclude them as potential wage bargainers is revealed in the next sentence:

There are therefore provisions in the Employment Contracts Bill to supplement the fiscal control of bulk funding by ongoing Commission participation in the bargaining of both collective and individual contracts (ibid.)
With provisions like these we wonder why there is any need for discussion over who should take the role of employer party!

Once again, we are forced to infer that the SSC believes that only the central agencies can be relied on to resist portfolio capture: participants in the portfolio culture can not be trusted with the portfolio. This is perhaps especially so in the case of education where the extent of teacher union involvement in policy at national (Ministerial) and local (Board of Trustees) level is seen as not only deeply regrettable but unique (see SSC Briefing, para. 34, quoted above). The SSC's fundamental role in the education sector appears to be to bring the portfolio culture into line with overall government policy through the rigorous application of the reforms of the machinery of government.

This is all well and good, but as this case demonstrates it is not by any stretch of the imagination, "policy-neutral". The setting of teachers wages and conditions cannot be separated clinically from other issues connected with education and schools. This is fully recognised at a number of points in the review of the SSC's role in wage bargaining. Though it argues that, "the divorce between industrial responsibility and general policy responsibility inherent in the Commissions' negotiation role within Education is an advantage to the extent that the SSC is not likely to accept weak industrial settlements in return for possible gains in other policy areas, where support of the teachers might be perceived by the Ministry as important" (para. 16) this advantage is seen to be clearly threatened by the disadvantages of that divorce. This is made clear in Paragraph 29 of the Review, which deals with Ministerial responsibility:

29. The Wage bargaining conducted by the Commission determines the baseline conditions under which the major input into the institutions from Vote: Education will be applied. If Settlements agreed by the Commission require tradeoffs to be found elsewhere in the Vote then the Minister of Education cannot be held fully accountable for educational outcomes from the management of Vote: Education. Similarly, savings achieved in wage bargaining must be devoted to purposes determined by the Minister of Education in terms of his or her Education policy for accountabilities to be maintained. Ministerial responsibility may be readily maintained in minimal structures of wage bargaining restricted to remuneration, 
leave, and allowances. It becomes blurred very quickly if negotiations on conditions move to such issues as class-sizes, or in-service training linked to teachers' hours of work, each with capacity for significant impact on Vote:Education.

It hardly needs such a paragraph to remind us of the inseparability of industrial relations and broader policy when teacher unions have placed an embargo on implementing educational initiatives as part of their industrial relations strategy. But the inseparability does mean quite clearly that the "employer party" in wage bargaining has a major influence on wider education policy. This may be relatively indirect, but it may channel and severely constrain policy possibilities. This is especially the case when, on the one hand we cannot be confident that any conflicts over Ministerial responsibility will be easily or amicably resolved, given the State sector review's comments (quoted above) on the mutual hostility of Ministers and central agencies, and on the other hand when what determines the "employer party's" strategy is the desire to make the education system as a whole conform to the new machinery of government - what we refer to as "mainstreaming" education. Educationally-derived policy options therefore follow rather than lead industrial relations-derived policies, whether directly, through the wages and conditions available to the different kinds of teachers, or indirectly through the overall constraints placed on the system.

This strategy is apparent in the Review of the Teacher-Pupil Ratio, as well (Ministry of Education 1991b). There is no space to go into this review here but it is worth noting that, the SSC in its dissenting view (which recommends the "suspension" of the current teacher-pupil ratio and the introduction of a higher teacher pupil ratio that could produce savings of \$100-200 million per year - which we calculate on the basis of the figures provided in the Review would mean an increase of 15$20 \%$ in that ratio), regards as inappropriate the present approach to deciding the teacher-pupil ratio which is driven by a formula based on calculation of educational need, in favour of a fixed budgetary allocation. It is clear that the formula-driven approach appears to be seen as a remaining relic of an input rather than output driven system, and that even in such a crucial, albeit complex and contested, area as teacher-pupil ratios the education sector should not be allowed to claim special treatment, when "other sectors have to make price/quality tradeoffs within an overall salary budget."

\section{The Education Amendment Bill}

The final example we wish to examine is the Education Amendment Bill No. 5 of 1992, which was, quite significantly, written by the SSC. ${ }^{5}$ What the Bill amended was the clause in the 1989 Education Act that prevented the bulk funding of teacher salaries. Of the two main components of the Bill, one extends bulk funding to cover the salaries of "management" staff in all schools, (these staff have now been defined as at least PR3-Principals in secondary schools, Principal to F3 in area schools and Associate Principals in primary schools). The relevant section of the Bill (Section 91E) states that the Board of a payrolled (i.e., currently not bulk funded) school may be required by Order in Council (i.e., by Cabinet decision) to pay out of the grants paid to it, the salaries of teachers. This is specified for management staff later in the clause, but as the Legislative Advisory Committee points out in its submission (written, ironically, by Mervyn Probine, head of the SSC until 1986):

The clause goes far beyond the press statement of the 7th July (1992) [which announced the bulk funding of management salaries]. It provides general terms for the determination of categories of teachers without any constraint at all in terms of seniority. While the word partial appears in the heading to the section that is the only indication that the Order in Council made under it might not extend to every teaching position in the school ... the powers conferred by $91 \mathrm{E}$ are much too broad.

The other main component of the Bill enables the funding of schools to be capped by Order in Council. Clause $91 \mathrm{H}$ states that "the Governor General ... may impose on the boards of payrolled schools general limitations on the numbers, kinds and descriptions of regular teachers they may employ during the next year."

The timing of the announcement of this proposal gave rise to a number of furious objections from interested parties. It was announced without prior consultation with either teacher unions or the School Trustees' Association. ${ }^{6}$ The announcement came while schools were on mid-term break and before the results of the elections to Boards of 
Trustees (which had been held under the old system) had become known. And finally it was an announcement by the employer party when that employer was in negotiation with the union over issues crucially affected by the proposed amendment.

The nature of the announcement predictably enraged the teacher unions. The introduction of the Bill was seen as a blatant breach of faith. Political assurances had been made that bulk funding would not be imposed at least during the time of the three year trial. The primary teachers' union (NZEI) co-ordinated an enormous submission against all forms of salaries bulk-funding, and both unions imposed a moratorium on the implementation of the Achievement Initiative. By upsetting the Minister of Education's plans for the new curriculum initiatives, the Curriculum Moratorium had the effect of drawing the attention to the impossible split which was being attempted by the SSC between what were professional issues and those which were being designated as industrial ones. It was both the teachers' professional skills which the curriculum change needed and the active support of their associations.

Perhaps less predictable was the strength of the reaction by the School Trustees' Association. They were angered by the coincidence of the announcement with the Board of Trustees elections, and their submission to the select committee on the Bill stated that its introduction had seriously eroded Board of Trustees" "confidence and respect in government assurances." Their submission stated, in respect of 91E that "control of management of schools is vested in Board of Trustees and not to be exercised by Order in Council." By using the latter, Government provided no opportunity for consultation. STA was even more trenchant on clause $91 \mathrm{H}$ :

the effect of this clause is that Boards of Trustees will end up being responsible for decisions into which they have had no input. The clause nullifies the whole concept of self-management, imposes control, restricts forward planning by boards and disables opportunities for choice and initiative ... funding will be dependent on the Government's financial position rather than to (sic) the educational needs of students.

Fundamental to both the unions' and the trustees' objections to the Bill are the shift of the locus of control over schools that it implies, from individual schools to central agencies, and the shift in the basis of educational decision making, from an educational basis to a cost or management basis. These objections centre in particular on the Bill's designation of who constitute "management" and "non-management" staff in schools by legislative fiat, based on existing distribution, rather than allowing schools the flexibility to designate such staff on the basis of their perceived educational needs. On the face of it, these elements of the Bill, which became an Act of Parliament on 7 December 1992, represent a very significant departure from the Picot principle of devolving decisions to the point where they have most impact. They give further substance to the argument that what the whole education administration reform process has resulted in is the devolution of administrative responsibility to volunteer Boards of Trustees and the centralisation of control over the system.

\section{Conclusions}

Overall the main characteristics of the SSC's involvement in the education reforms have been that it has sought, quite successfully, tolay down the terms on which the reforms were to be considered and has implemented and monitored a new framework for education administration that has as its objective the "mainstreaming" of the education service. We will briefly outline what seem to us the main features of that involvement and look at some of its consequences.

The first feature of that involvement is its almost exclusive concentration and reliance on management rather than educational issues. A starting point for this article was that the central purpose of the SSC's intervention in education was to mainstream the education service, that is to bring the education service into conformity with the broader reforms of the public administration and deny it any special treatment. The education reforms, that is, are much more part of and much more marked by the reform of public administration than they are to do with direct changes to education.

These changes have, of course, had consequences for education and we will discuss these below. It is worth noting, however just how "noneducationally informed" these interventions initiated by the SSC have been. Three examples illustrate this. The first is the relatively limited use of their powers made by the Boards of Trustees. MacPherson (1989) referred to the "unimaginative" and "technicist" use of such powers, which he put down to principals developing false confidence through 
the use of managerialist technicism, where they lacked the experience and expertise to discharge their new duties. As he puts it:

The concern to encourage responsiveness and to localise responsibility appears to have given less priority to learning how to articulate what is best and significant in education and to providing appropriate means for educators to realign their assumptions about social reality and to legitimate new practices (MacPherson, 1990, p. 8).

This judgment was based on experience of the early stages of the implementation of the reforms but it is largely confirmed by the surveys of Board of Trustee members' views on their work and activities which point to the dominance of administrative and managerial issues (see e.g., Wylie, op. cit.).

The second indication of the absence of any educational vision or even perspectives in these reforms is the very narrow conception of the "outputs" of education contained within the SSC papers. There appears to be little recognition that schools are involved in any anything but producing credentials, a criterion that is to a greater or lesser degree inappropriate for all schools.

Associated with this is the third educational absence, the lack of any reference at all to the enormous literature about school effectiveness. This is especially noticeable since that literature does indicate a range of educational outputs and ways of registering schools' effectiveness in providing them. Moreover, it does so, in the majority of cases, using a set of assumptions that are quite compatible with those informing the SSC's assumptions about public sector management (see Dale, 1991).

A further broad conclusion is that the effect of the SSC's involvement in the education service has been extended beyond monitoring and advice to a point where it has laid down parameters and where it, rather than the Ministry of Education, is the de facto collective employer in the service.

There are several bases for this conclusion. First, as suggested above, the Lough Report can be seen as a re-litigation and managerialist extension of the reforms contained in the Picot Report and Tomorrow's Schools. It is also hugely undermined the possibility of professional accountability and monitoring. This means that the SSC both lays down the management structures and monitors them. Further the Education Amendment Act 1992 has the effect of determining the levels and definitions of management and non-management positions in schools at central government level. The allocations are determined on managerialist rather than through educational principles and are likely to create managerial rather than professional hierarchies. Similarly the Amendment Act allows the level of funding to schools to be determined by the resources considered available by the government rather than the educational needs.

As we pointed out above, the Commission is effectively the employer of teachers. Beyond this, however, it provides advice in the form of regular bulletins to the hundreds of individual Boards of Trustees, who already have responsibility as employers of non-teaching staff. This role may be expected to persist beyond. Indeed it may be seen to anticipate enterprise bargaining in schools, just as it has in the tertiary sector, where the Commission's role is much more active than that of an observer.

Finally, its policies appear to be informed not just by an enormous fear of teachers' capture but by a mistrust of almost all those involved in education apart from the central agencies. ${ }^{7}$ We have noted a number of examples of this above. This mistrust of elected Boards of Trustees is evident from their exclusion from the Education Review groups set up in December 1990; they are evidently "interested parties" and hence unreliable. The assumption that they are considered to have succumbed to the culture of the portfolio they have been elected to support, is reinforced by a statement from the Associate Minister of Education that "the exclusion of teachers and school trustees from the education reviews is to avoid special interest being pushed." (quoted in Wylie, 1992 , p. 184)

The main purpose of this paper has been to outline the SSC's intervention in the structure and process of the education service. Some of the consequences of these interventions have been immediate and obvious, but it may be worthwhile to end the chapter with some more speculative considerations about the effects of the moves towards the "mainstreaming" of education.

As we have argued, decisions about education policy and practice are now less likely to be made by people with experience in education and on what had previously be recognised as educational grounds. This "educational" category is not confined to teachers and other education professionals, the providers whose "capture" of the system remains at the core of the SSC's concerns; it involves the whole portfolio culture. At the same time the education system still experiences a high degree of central control, though now that control is exercised on managerial 
as much as educational grounds. Indeed, we might say that the effect of the SSC's intervention on the educational service has been centralisation for managerial purposes but automisation for professional purposes. This is a tendency that seems unlikely to be modified if or when bulk funding and enterprise bargaining are introduced. However it is also evident that one consequence of the SSC's interventions (among other moves made by governments of both parties) has been not only to unite and strengthen the union voice, but also to make that the only organized and effective voice in the education sector. Further, as we have seen, that "educational" influence can not be wholly separated from the managerial. We might note, too, the irony of this outcome to a reform period set in motion by the Picot report, one of whose main arguments against the previous system was that its degree of centralization encouraged pressure group politics.

One way of speculating about the broader consequences of the SSC's interventions in education is to consider what changes they are likely to bring about in the combination of educational vision, school image and institutional effectiveness. These might be loosely linked to the differing missions of the education system, the Treasury and the SSC respectively that inform the work of individual schools (see Dale, 1993). On the face of it, a greater emphasis on institutional effectiveness would be the obvious outcome. However, as we have just noted, the basis for the promotion of educational vision has not been wholly extinguished. Further, and somewhat ironically, with the passage of the Education Act amendments, the SSC established the mechanism whereby the Treasury's concept of establishing a simulated market mechanism for education, i.e., PRICE rather than costs, could now be legally imposed. The desire of the SSC for a change in the culture of the schools, to move them from a "professional" culture to a managerial culture committed to the efficiency ethos, established the mechanism for implementing the neo-liberal agenda. Though the parameters and the terrain of educational policy and practice may have been profoundly altered by the SSC's strategy of "mainstreaming" education, the consequences of the specific interventions involved are by no means wholly determined.

Already by 1990, Peter McKinlay was suggesting that:

the public sector reforms [that] culminated [sic] in the State Sector Act 1988 and Public Finance Act 1990 ... seem to be resulting in a major recentralisation of power. Specifically, central agencies have been able to change the onus of proof in respect of expenditure. The evil which those reforms sought to remedy was the ability of major departments of state ... to resist any serious attempts to cut back their access to resources.

And he concludes that:

It is these reforms, rather than the changes within individual policy areas, which will have the major impact on the distribution of power between central government agencies and other elements within society. (McKinlay, 1990, pp. 3A)

The process he describes has been intensified since 1990 and we have described some of that process of intensification in the education sector. Finally, however, we should draw attention to a broader issue raised by this consideration of the SSC's interventions in the education system. It is, in essence, a constitutional issue. What we have shown is the ability of one of the two central agencies in government to have a considerable element of control over the work and policies of another Ministerial portfolio (and, of course, the other central agency, Treasury, is already notorious for using its ability to monitor the work of the Government departments). The great concentration of scarcely challenged power in the Cabinet in New Zealand that results from the single house of parliament, little limit on executive power, little challenge from major organized sectors of civil society, and a powerful parliamentary caucus system, is well known. The evidence we have presented points to an even greater concentration of power in the hands of the Prime Minister and the political heads of the Treasury and the State Services Commission. This must represent a far greater threat to the democratic system than the overloaded government it has been installed to replace.

Notes

1. This paper draws on the theoretical assumptions about the relationship between the state and education set out in Dale, 1988 and Dale \& Ozga, 1990 , and on the analysis of the background to the New Zealand education reforms in Dale 1992 and Codd, Dale and Gordon (forthcoming).

2. See "Professor reveals pressure put on Picot Report" New Zealand Herald, 25 July, 1988.

3. This paragraph draws heavily on a paper prepared by Marijke Robinson of the SSC entitled "Factors for Consideration in Restructuring the Public sector".

4. Whitcombe describes the Treasury and the SSC as control agencies. 
However they are described elsewhere as central agencies. We believe that Whitcombe's term is much more accurate both philosophically and structurally.

5. New Zealand Herald, 23 September, 1992 "Commission hand in funding bill" by Andrew Stone.

6. Interestingly, the press statement was released by the Ministry of Education but delivered by the Minister of State Services, Mr Birch, who also fronted the ensuing press conference, with what the NZ Herald described as the "nominal" Minister of Education speaking second. (NZ Herald, 11 July, 1992)

7. Perhaps "mistrust" is not the right word, if it implies a fear of personal dishonesty or irresponsibility. It seems clear that, from the several points that we have touched on, what the SSC fears is that the danger of politicians and members of portfolio cultures succumbing to short term pressures is a chronic structural feature of parliamentary democracy. There are echoes in some of their statements of Hayek's suggested separation of government and legislation. When the two tasks are entrusted to the same representative assembly, Hayek argues, "a representative assembly organized in the manner necessary for efficient government, and not restrained by some general laws it cannot alter, is bound to be driven to use its powers to satisfy the demands of the sectioned interests" (Hayek, 1973, p. 18). To ensure the "restraint of general laws it cannot alter", Hayek suggests creating a legislative assembly, "not concerned with the particular needs of particular groups but rather with the general permanent principles on which the activities of the community were to be ordered" (ibid, p. 19). The members of such a legislature would not have been involved with political organisations, would be elected for 15 years, and should be chosen by and from one age group (ibid). The purpose of this separation of powers is to create a legislature which, as Littlechild points out in words that might almost act as a motto for the government central agencies, "is not subservient to the momentary pressures of government, and hence which severely limits the response which governments may make to immediate political pressures in order to protect the long-run interest of these same people" (Littlechild, 1978, p. 79). One model for this kind of separation, of course, is the role of the Reserve Bank and its inflation target. One of us has indeed suggested that one purpose of the introduction of school charters with $80 \%$ of their content centrally laid down was similarly to effectively "de-politicise" education (see Dale, 1990). Evidently, in the view of the SSC, this still leaves excessive scope for the portfolio culture. This position which appears to want to limit school's responsiveness and flexibility sits rather uncomfortably with the Treasury emphasis on responsiveness. Treasury's eagerness to increase responsiveness, (see above, p. 15) without any apparent fear of the consequences, contrasts strongly with the kinds of fears expressed about how the individual Boards of Trustees might use their flexibility (see below p. 16). Speculatively, we might suggest that this signals a further dimension of the differences between the SSC and Treasury. The latter's concept of responsiveness is largely an economic one; it assumes that schools will respond to market signals like any other market player, changing to please the market or going bust. It is a view that looks beyond the present structure and provision and assumes its modification. The SSC, by contrast, sees schools responding not as market players, but still as state institutions. Its stance is based on calculations of immediate political risk rather than a superior economic future.

\section{References}

Boston, Jonathan, Martin, John, Pallot, June and Walsh, Pat Reshaping the State: New Zealand's Bureaucratic Revolution. Auckland: Oxford University Press, 1991.

Codd, John, Harker, R. and Nash, R. (eds) Political Issues in New Zealand Education, 2nd Edition. Palmerston North: Dunmore Press, 1990.

Codd John, Dale Roger and Gordon Liz The Legacy of Tomorrow's Schools: Educational Reform in New Zealand. Auckland: Auckland University Press (forthcoming).

Dale, Roger The State and Education Policy. Milton Keynes: Open University Press, 1989.

Dale, Roger The Impact of the Restructuring of Education in New Zealand and Britain. Paper presented to the 2nd Research into Educational Policy Conference, August, Wellington, 1990.

Dale, Roger "School Effectiveness Research and Theories of the School Management" in Peddie R. and Alcorn, N. (eds) Theory and Practice of Educational Management. Auckland: Educational Administration Society, 1991.

Dale, Roger "National Reform, Economic Crisis, and 'New Right' Theory: a New Zealand Perspective", paper presented to AERA Annual Meeting, San Francisco, 1992

Dale, Roger "Constituting School-Centred Leadership in New Zealand" in Stephen J. Crump (ed) School-Centred Leadership. Sydney: Nelson, 1993.

Dale, Roger and Ozga, Jenny Theoretical Approaches to Education Policy making: E333 module 1. Milton Keynes: Open University, 1990.

Gianotti, Maurice "Educational Administration: Reflections on the Picot Report" in Phillips, D., Lealand, G. and MacDonald, G. (eds) The impact of American Ideas on New Zealand Educational Policy, Practice and Thinking. Wellington: NZUS Ed. Foundation and NZCER, 1989, pp. 190-198. 
Gordon, Liz"The bulk funding of teacher's salaries: a case study in education policy" in Manson H. (ed) New Zealand Annual Review of Education, 1:1991. Wellington: Victoria University, 1992.

Grace, Gerald “Education: Commodity or Public Good?" Inaugural lecture, Victoria University of Wellington, 1988.

Grace, Gerald "The New Zealand Treasury and the commodification of education" in Middleton, S., Codd, J. and Jones, A. (eds) New Zealand Education Policy Today. Wellington: Allen and Unwin, 1990, pp. 27-39.

Hayek, F. A. Economic Freedom and Representative Government. Government Occasional Paper No. 39. London: Institute of Economic Affairs, 1973.

Henderson, Allan The Quest for Efficiency: the Origins of the State Services Commission. Wellington: State Services Commission, 1990.

Holland, M. and Boston, J. (eds) The Fourth Labour Government. Auckland: Oxford University Press, 1987.

Holland, M. and Boston, J. (eds) The Fourth Labour Government. 2nd Ed. Auckland: Oxford University Press, 1991.

Lauder, Hugh and Wylie, Cathy (eds) Towards Successful Schools, London: Falmer, 1990.

Littlechild, Stephen The Fallacy of the Mixed Economy. Hobart Paper No. 80. London, Institute of Economic Affairs, 1978.

Lough, Noel Today's Schools: A review of the Education Reform Implementation process. Wellington: Ministry of Education, 1990.

MacPherson, R. J. S. "Why Politicians Intervened Into The Administration of New Zealand Education." Discourse 15, 2, 1989, pp. 107-112.

MacPherson, R. J. S. "The Reconstruction of NZ Education: A Case of 'High Politics' Reform?" Paper presented to IIP Conference, Manchester, April 1990.

MacPherson, R. J. S. "Challenging 'Provider Capture' with Radical Changes to Educational Administration in NZ" in Martin, Yvonne, M. \& MacPherson, R. J. S. (eds) Restructuring Administration Policy in Public Schooling: Canadian and International Perspectives. Calgary, Alberta: Detselig, 1993, pp. 229-248.

Manson, H. (ed) New Zealand Annual Review of Education, 1:1991. Wellington: Victoria University, 1992.

Middleton, S., Codd, J. and Jones, A. (eds) New Zealand Education Policy Today. Wellington: Allen and Unwin, 1990.

Ministry of Education Review of the Role of the State Services Commission in Wage Bargaining in the Education Sector. Wellington: GP Print, 1991a.
Ministry of Education Review of the Teacher:Pupil Ratio. Wellington: GP Print, $1991 b$.

Picot, Brian Administering for Excellence: effective administration in education. (Picot Report) Wellington: Government Printer, 1988.

Sexton, Stuart New Zealand Schools: An evaluation of recent reforms and future directions. Wellington: New Zealand Business Roundtable, 1991.

State Services Commission Briefing to the Incoming Government. Wellington: State Services Commission, 1990.

State Services Commission Review of the State Sector Reforms. Wellington: State Services Commission, 1991.

Treasury Government Management: Brief to the Incoming Government, Vol. Two, Education Issues. Wellington: Government Printer, 1987.

Whitcombe, J. The Accountability Relationship between Chief Executive and Minister under the State Sector Act 1988. Public Policy Research Paper No. 3. Wellington: Victoria University, 1990.

Wilson, Ken "The Picot Report and the Legitimation of Education Policy". Unpublished M. Ed. Admin. Thesis, Massey University, 1991.

Wylie, Cathy The Impact of Tomorrow's Schools in Primary Schools and Intermediates - 1990 Survey Report. Wellington, NZCER, 1991.

Wylie, Cathy "Trustees' Perspectives on 1991" in Manson, H. (ed). New Zealand Annual Review of Education, 1:1991. Wellington: Victoria University, 1992, pp. 173-186.

\section{The authors}

Roger Dale has been Professor of Education at Auckland University since 1989. Prior to that he spent 19 years at the Open University in England for whom he wrote a large number of texts and edited several collections of readings in the sociology of education where he has also published numerous articles. His main current interests are reflected in the title of his book The State and Education Policy, and he has co-authored with John Codd and Liz Gordon a study of the New Zealand education reforms to be published by Auckland University Press in 1993.

Joce Jesson is a Senior Lecturer in Science Education at Auckland College of Education. She has taught at Onewhero DHS, Tuakau College and Auckland Girls' Grammar School where she was a Deputy Principal. Her particular interest is political sociology in education and she is currently investigating the changing role of a teachers' union in the structures of education. 